\title{
A Rather Late Letter from Wroctaw
}

Wrocław was perhaps an unlikely place to spend four chilly and rainy days in mid-October, 2007, but there I was, invited to the Międzynarodowy Festiwal Opowiadania. That's "International Short Story Festival" in Polish. International it was: My non-Polish colleagues included Helen Simpson (England), Rachel Trezise (Wales), Segun Afolabi (Nigeria), Michael Kasper (United States), Jan Balabán (Czech Republic), Vladimír Balla (Slovakia), Miroslav Mićanović (Croatia), Viktor Erofeyev (Russia), and Maike Wetzel (Germany). Having lived in France for more than thirty years, a period far exceeding the time that I spent in my American hometown (Des Moines, eighteen years) or the United States in general (twenty-three years), I was appropriately defined as a "FrancoAmerican." So be it, that's the way it is, "tak to juz jest." Besides these authors were ten Poles, several of them practitioners not so much of the short story as of short prose or, simply, unusual prose both long and short. Whence the interest of this conference: the possibility of reading and hearing narratives-when translations were forthcoming-composed in prose forms sometimes starkly different from those of the standard short stories filling most American journals. And when English translations were unavailable, I would try to grasp the overall formal orientation of some of this Eastern European writing, a challenging task in that like our own public readings in English, those in Czech, Russian, and other languages were accompanied by Polish translations only, projected on a screen above and behind the writer as he or she was reciting from an armchair set in the center of a stage with some rather surrealistic props, including patches of real grass and a life-sized replica of a pig.

Before flying from Paris to Warsaw, and from there to Wrocław in southern Poland, I spent an evening and then a full day in the city in which the Polish poet and former Parisian Adam Zagajewski, as he recalls in W cudzym pięknie (1998), translated as Another Beauty, would "mumble bitterly under his breath without the cats or children paying the slightest attention." "This is the emigrant's 
lot," he adds. Apropos, with time thus on my hands, I browsed for books at the Księgarnia Polska, the famous Polish Bookshop on the boulevard Saint-Germain. It has been in business ever since 1833, that is two years after thousands of Polish emigrants-among whom were writers, artists, and intellectuals-had fled to France during the Russian czar's repression of revolts of Poles hoping to re-establish sovereignty over and acquire independence for lands that had been annexed. In times of political turmoil ever since then, and notably during the communist regime (which began to break up with the Solidarity trade-union movement of 1980 and finally collapsed in 1989), this bookshop distributed and was often closely associated with the publication of Polish writing that was prohibited in the homeland. This bookshop sold the original volumes of work by Zagajewski, Zbigniew Herbert (also a former Parisian), Wisława Szymborska, and so many others-not to mention Czesław Miłosz who, in a 2003 interview with Malgorzata Anna Pachalén, pertinently observed that the most distinctive feature of Polish literature was "without doubt [its] constant struggle with history." Today the Librairie Polonaise is linked to the Éditions Noir sur Blanc, an excellent press specialized in the translation of Eastern European literature.

From a bookshop table I picked up Andrzej Stasiuk's Sur la route de Babadag, the recent French translation of his-as I was to discover just an hour later at the back of a bus-absolutely brilliant Jadac do Babadag (2004). By the way, I keep citing Polish words as if I already knew the language; no, I did and do not, but because of recent trips to Slovenia, Bosnia, and Croatia, and some earlier prolonged dabbling in Russian and Czech, I knew more than a few words of Pan-Slavic, as Stasiuk terms the lingua slavica that Czechs, Slovenes, Poles, Russians, Ukrainians, and so on concoct by appealing to common etymological roots in order to communicate with each other. (English is supplanting Pan-Slavic: a pity.) Armed with a Berlitz phrasebook and a pocket dictionary, I was resolved to learn some Polish while I was in Wrocław.

Stasiuk's book relates car and hitchhiking trips through the most obscure and impoverished regions of southern Poland, Slovakia, Hungary, Ukraine, Moldavia, Slovenia, Romania, and Albania. In an age when tourists crowd into spotless museums, this Polish- 
styled On the Road describes what only a few hardy voyageurs wish, and dare, to see up close. Stasiuk offers the most vivid, precise, and philosophically resonant descriptions of ugliness, depravity, decrepitude, and in-the-middle-of-nowhere-ness that I ever read. His travelogue immediately became my trip within my trip. What I mean is that I was also in "a terra incognita between Radom and Sandomierz" as I hopped off the bus near the tree-canopied place Turgot. "The sky, the trees, the houses, the ground," I had just read, "all this might have been located absolutely anywhere. I was moving through a space lacking history, events, notable accomplishments. I was the first human being ever to set foot in this spot somewhere near the Góry Pieprzowe; everything commenced because of my presence. Time went by, things and landscapes aged, only when I gazed at them. After Tarnobrzeg, I knocked on the steel roof of the pickup driver's cab. I had been dazzled by the sight of an immense open sulfur mine and I just had to climb down."

While I was in Wrocław, I filled several pages of a small blue and green notebook with quotations from Stasiuk's masterpiece, which I would read at the hotel until the wee hours of the morning (and I am an early riser). Several of his insights and resolutions pertained to my trip to Wrocław ("I had come for only three days and I needed to give myself over completely to whatever happened") - but note that I was not entirely heeding Stasiuk's advice because I was also still traveling with him, for example in Krompachy, Slovakia, where a Gypsy settlement "rose into the sky" in a manner that could hardly be more amusingly different from that of the equally towering, four-star, international hotel in which we, the festival participants, were staying:

To the left of the road, on a nearly vertical slope, their houses sprouted out of each other, as it were, the highest perched among them seemingly planted in the infinite azure like wild and wacky aerial constructions leaning against pure space. Exposed to the wind and the rain, suspended in emptiness, defying the universal law of gravity, the towering shambles made one think of a colony of bird nests attached to a rock cliff. Everything extended too far, nothing fit together, everything was sagging as if in the very next moment all the houses would slide and then come crashing down in a roar onto the street-poles, pieces of sheet metal, sticks, 
broken-off sections of old houses in which nobody wanted to live anymore, brought there from who knows where, mud and moss in the cracks of roof beams, debris of tarpaper stuffed into holes with stones, all of these things picked up somewhere and put to use with extraordinary ingenuity.

In Room 522, I could hardly marvel at the shiny tiled bathroom, the vacuumed carpet, the slick counter of the desk attached to the wall, the vast mirror, or the silent dark-gray television set, but visible from my window was a candidate for the tallest smokestack in the world: painted Polish red and white, it rose toward heaven just beyond the city center and was apparently part of the municipal heating plant.

Now that I am leafing again through Sur la route de Babadag, nostalgic but also still grateful for the feverish atmosphere in which I first read it (and because of it and insomnia, I was dragging a slight fever around with me to the Festival and through the cold, downpour-drenched streets), let me cite one more appropriate passage, actually marked off in pencil by my wife, who read the book after I had returned:

It is good to go to a country about which one knows nearly nothing. Thoughts henceforth become silent, useless. Everything needs to start all over again. In a country about which one knows nearly nothing, memory loses its meaning. Colors, odors, and indeterminate recollections can thus be compared. Life becomes rather infantile and animal-like. Objects and events indeed evoke something, but, in the final reckoning, they manage to transform themselves into nothing else but themselves; they ultimately remain what they are in reality. They begin at the very spot where we noticed them and they end immediately, replaced by others. In truth, they lack signification. They consist of an original kind of matter that surely affects our senses yet it is too lightweight, too delicate, to teach us a lesson.

It occurs to me that some of the tensions of contemporary Polish writing can be felt by situating oneself in the triangular space between Miłosz's remark about history (as well as others that the 
author of Facing the River made about metaphysics) and Stasiuk's emphasis on the overwhelming material presence of the present.

Wrocław is laced with tributaries and various forks of the Odra River (Oder in German) and its 121 bridges, an impressive number that was mentioned by one of my chaperones, a poetry-loving hydrology student who, when I expressed my admiration for modern Polish verse (and added that I had also discovered with enthusiasm the work of Piotr Sommer and Marzanna Kielar), looked at me solemnly and declared: "In a country such as ours, which has sometimes been no country because of a history such as ours, poetry has often been the sole medium of truth." He then explained that the water system of Wrocław had been rigorously engineered by Germans back when the increasingly Germanized city, then called Breslau, was a part of the German Empire. The system had fallen into decrepitude during the communist decades; the July 1997 flood, which covered most of the city, grimly demonstrated that repair and renovation were urgent. Ten years later, every morning when a group of us crossed the Uniwersytecki Bridge on our way to the Festival, I would pause to watch workers patching a retaining wall along one of the riverbanks. We would thus cross the Odra, quite wide at this spot, then a busy and cacophonous expressway-like avenue that functions psychologically as - and probably also covers the medieval foundations of - an enemy-intimidating rampart for the city center, the Old Town. Having arrived safely on the other side of the perilous avenue, we could finally pass beneath a massive portal and find ourselves in a quiet square flanked by the eighteenth-century buildings of the University of Wrocław. A picturesque fountain greets the stressed pedestrian.

I'll let you look up as many facts as you wish about the "stormy yet colorful past" (as the tourist brochure, Let's Meet in Wroctaw, euphemistically puts it) of the town, which was founded at least a thousand years ago as a bishopric. However, one fundamental aspect of modern history cannot be avoided because the topic is brought up even in the conversations of students born in the mid- to late-1980s, who therefore barely knew communism, let alone the Second World War. Wrocław, or "Fortress Breslau," was the last city in the German Reich to surrender, four days after the surrender of Berlin. The Nazi Gauleiter, Karl Hanke, had forced 
the freezing, starving civilian population to resist the Soviet siege, which eventually caused the deaths of as many as-the figures are still debated and vary greatly-170,000 civilians. Many of the civilian deaths occurred earlier that winter, when Hanke forced thousands to evacuate the "fortress" and flee through icy storms and $-20^{\circ} \mathrm{C}$ weather. Seventy percent of the town was eventually destroyed, a state of utter ruin that is not at all perceptible in the smoothly restored "historical" Old Town through which I strolled. (I was told that the rubble of Wrockaw was transported north to Warsaw, so that the Polish capital could be rebuilt as a priority for the communist regime already in power.) In any case, today's city of about 635,000 souls constantly struck me as charmingly yet thus deceivingly quaint, both intimately scaled and vast, as each medieval-looking public square that I walked onto was somehow larger, and especially longer, than I thought it should be with respect to the height of the surrounding townhouses and buildings with their pleasant pastel-colored façades.

At the end of the Second World War, another essential event occurred. After surrendering, Breslau came under Polish rule and was re-christened Wrocław in accordance with the agreements of the Yalta and Potsdam Conferences. The borders of Poland were moved westward. The German inhabitants of Wrocław were mostly deported to East or West Germany, while their homes and property were given to Poles who resettled there from central Poland or from eastern Polish regions annexed by the Soviet Union. The parents of some students and writers whom I met had been displaced from towns like Lwów/Lviv, Wilno/Vilnius, and Grodno/Hrodna that are now in Ukraine, Lithuania, or Belarus. Note that for such towns, I am providing only two of several different spellings. Such is Eastern Europe: an orthographic palimpsest. Wrocław/Breslau has also been called at least Wortizlawa, Vratislav, Wrocislaw, Wrotslaw, Wrotizla, Wratislavia, Wracislavia, Vretslav, Prezla, and Presslawand please insert the diacritical marks for those names if you can. When the Germans were evicted, almost all traces of their language were effaced from signs and inscriptions. I kept looking for exceptions, especially on obscure iron, steel, or brass objects-ranging from manhole covers to doorknobs-that might have survived the destruction. The interesting aluminum litter barrels with attached cigarette extinguishers were much too recent for investigation. As 
were the tiny brass dwarfs or gnomes that one finds peeking out from unexpected nooks and crannies on streets and squares-funny trolls that go by the name of "Wrocławskie krasnale" in Polish and "Breslauer Zwerge" in German. Only various examples of Hapsburg architecture recall the former cultural omnipresence of the Germans; one such reminder is the stolid Opera House, which stands diagonally across a noisy and crowded pedestrian-only street from the Teatr Polski, the former Jewish theater in which the Short Story Festival took place. Der Freischütz was playing at the Opera that week.

This induces a further observation. A historical aspect of Wrocław that was glaringly visible to me because it was nearly everywhere invisible was the absence of the Jewish community, which was one of the largest in Poland and whose beginnings go back to the twelfth century. (In 1871, Breslau had the third largest Jewish population in the German Empire, after Berlin and Frankfurt.) The repression against local Jews began immediately in 1933 with the rise of Nazism; by 1935 they had lost their German citizenship; it is estimated that 8000 Wrocław Jews perished in the camps of GrossRosen, Kowno, Terezin, and Auschwitz. Many Polish non-Jews were also evicted from the city in 1938. According to Norman Davies and Roger Moorhouse's Microcosm: Portrait of a Central European City (2002), Wrocław was almost entirely "Germanized" by 1939. This preliminary ethnic cleansing enabled the German air force, when the Reich invaded Poland in 1939, to take off from a Beslau airport and bombard Polish cities.

The Jewish community has revived a little in recent years, I am told; its activities are concentrated around the White Stork Synagogue on the outskirts of the Old Town. Otherwise, this city that also, beginning in 1523, deeply experienced the Reformation, is now pervaded by Catholicism. The most striking display can be found on Ostró Tumski, Cathedral Island. There stand chapels, the Holy Cross Church, and especially the looming brick Cathedral of St. John the Baptist, whose two gothic towers, along with the aforementioned red and white smokestack, dominate the skyline of the town. Among these religious edifices are numerous other ecclesiastical buildings, outside one of which I was able to admire several genuine gas lamps: the becs de gaz that are systematically mentioned in nineteenth-century French novels yet that have disappeared com- 
pletely from Paris. All over Cathedral Island, as well as elsewhere in the city, portraits of the late John Paul II were ubiquitous.

So ponderous was the Catholic atmosphere on Cathedral Island that I started wondering-I had just read, at the Festival, from my book The Apocalypse Tapestries, partly based on the Book of Revelation and the Gospel of John-if it were possible to joke about Catholicism. I was of course aware of the decisive role that the Catholic Church (and Karol Wojtyla in particular) had played during the Solidarity movement. Would poking fun at the Vatican by alluding, say, to its stalwart stand against birth control and sexual relations before marriage be in bad taste? Of my student chaperones, a Polish literature major who was writing a master's thesis in queer studies and whose politics were overtly radical was precisely the one who genuflected the most dramatically when she and two of her classmates were showing me around several other churches in the Old Town. Elections were scheduled for the Sunday we would depart and like all except one of the students with whom I talked, she was adamantly against the conservative Prawo i Sprawiedliwość (Law and Justice) Party run by the Kaczynski twins, who espoused the Vatican line in regard to morality. Yet all the students genuflected, or at least crossed themselves ostentatiously, whenever we entered churches. A handful of bright young people constitutes no legitimate population sample, but their opinions nonetheless persuaded me that history, Catholicism, vestiges of Communism, politics in general, and contemporary mores are intermingled in ways that are not easy to untangle for an outsider, especially for a FrancoAmerican accustomed to the sharper politico-religious cleavages of his adopted country. In any event, at the Muzeum Narodowe, the National Museum, you come across-not far from several arresting painting-sculptures involving umbrellas, fashioned by the playwright Tadeusz Kantor (1915-1990) - an at once solemn and satirical collage-like sculpture made by the provocative Eugeniusz Get Stankiewicz (b. 1942). It is the size of an average painting and features an empty crucifix in the center, a Christ figure with upraised arms to the left and, to the right, a hammer and three nails. The inscription reads "Zrób to sam," "Do it yourself." This work of art may provoke a grin, as it did in me, but it ultimately confronts an individual with his or her sense of responsibility-a key Polish theme that can also be employed as a touchstone, I would suggest, 
for measuring the evolution of Polish literature. Not all my chaperones knew that this same sculpture (dated 1976) can be found on a wall not immediately visible to shoppers hurrying in front of the so-called Hansel and Gretel Houses on the vast Market Square.

One writer attentive to the consequences of population displacement is Olga Tokarczuk (b. 1962), a skilled storyteller who is keen on reflecting the complexities and discontinuities of contemporary Polish consciousness through subtly crafted composite novels. Her Dom dzienny, dom nocny (1998), available in English as House of Day, House of Night, is an oft-dreamy chronicle woven out of multifariously structured short prose texts that all revolve around Nowa Ruda, a small Silesian town that is located near the Czech border and that ethnically metamorphosed, like Wrocław, when the German inhabitants were evicted. Several texts describe Germans returning to visit the town-formerly Neurode-in which they had lived before the war, a pilgrimage that occurs frequently in Wrocław as well. On my last morning in the hotel, the extensive dining room was filled with a busload of elderly breakfasting Germans who had arrived the night before; probably some of them are implicitly evoked in this excerpt from one of Tokarczuk's mini-stories:

One year an old couple turned up on our land and showed us where houses that no longer existed had stood. Afterwards we sent each other Christmas cards. They reassured us that the Frost family was no longer interested in our house.

"Why should anyone be interested in our house?" I asked Marta resentfully.

"Because they built it," she replied.

Tokarczuk's moving and sometimes comic prose mosaic about Nowa Ruda is much more than historical or sociological in focus, though she treats population displacement both seriously and engagingly. The most absorbing passages do not so much recount sequences of events as penetrate ever deeper into the souls of her characters, sometimes by detailing their dreams or hidden thoughts. Several different kinds of lives (and time periods) take shape in these pages, most memorably that of a monk, Johann, who is re-named Paschalis and secretly wants to be a woman. Tokarczuk blends Paschalis's 
tale with that of a painting of Kummernis, a legendary half-female crucified Christ. Yet this old story is juxtaposed with a situation as contemporary as a group of people anonymously sharing dreams over the Internet.

All along, the writer strives to give sense and shape to what the modern Pole, in this historically, culturally, linguistically, and ethnically tumultuous region, has experienced directly or indirectly. For all the heterogeneity of the narratives making up House of Day, House of Night, they revolve around a mysterious, unnamed core. The core is as personal as it is archetypal. Tokarczuk makes a selfrevealing remark when she describes Paschalis, who at one point is writing the life of Kummernis: "Kummernis went on living as long as he wrote about her as a living person, and she would never cease to exist, not even if he put her to death over and over again in his thoughts. And he realized that the aim of his writing was to reconcile all possible time scales, places and landscapes into one single image that would remain fixed, never ageing or changing."

Similar in its search for an overarching unity or ultimate reconciliation is Tokarczuk's Récits ultimes (Ostatnie Historie, 2004), which has just appeared in French. Consisting of three novellas respectively devoted to the grandmother, great-grandmother, and mother of a boy, the novel thereby formed out of these characters' "last stories" meditates on the passing of generations, population displacement once again, the centripetal and centrifugal forces of family life, and-as in Tokarczuk's other writings - the unsettling experiences that dreaming, remembering, and even a hyperawareness of present surroundings sometimes give us.

The first novella of this rich weaving of three lives begins with an automobile accident that jolts Ida out of her routines and forces her to reconsider her existence. The narrative soon shifts eerily between the present (as Ida convalesces in the nearby farmhouse of increasingly strange peasants, who have a barn full of sick and dying animals housed there by their veterinarian son, who does not ultimately put his customers' moribund pets to sleep-quite a symbol in itself) and the past, which surges forth in the form of dreams and memories that seem even more powerfully present than the present. In Tokarczuk's vision, we must come to terms with these uneasy blends of time past, time present, time future, and the unsettling space-time dimensions of dreaming. Needless to say, 
the historical and geographical backdrop makes the tales associated with these psychological depths even more compelling.

Another original short-prose writer whom I met in Wrocław is Natasza Goerke (b. 1960). Her third book, Pożegnania Plazmy (1999), has been issued as Farewells to Plasma (2001) by the remarkable, Prague-based, Twisted Spoon Press, who are also the publishers of Stasiuk's Tales of Galicia (1995/ 2003), which I likewise recommend because of his unforgettable graphic portraits of "both chaotic and cosmic" beings inhabiting a hinterland in which "categories of virtue and sin were indistinct and intermingled with one another, just like darkness and light before the first day of creation." Interestingly, Stasiuk's short-story collection gradually coalesces into a novel as distinct narratives are increasingly, and retrospectively, linked by common characters and allusions. Twisted Spoon has issued work by several important Eastern European writers who have thus far escaped the nets of American and British publishers. I'm especially impatient for the forthcoming release of The Passive Vampire by Ghérasim Luca, a Rumanian Francophone poet who has a special, not yet fully acknowledged, place in twentieth-century French literature.

It is hard to sum up Goerke's fifteen texts, whose plots, themes and, above all, humor take place on several levels all at once. Her translator, W. Martin, reports that Polish critics term her writing "surreal," "grotesque," "ludicrous," "ironic," and "extravagant," and adds that it calls "to mind the absurdist and parabolic traditions of Daniil Kharms, Cristina Peri Rossi, Sławomir Mrożek, Juan Carlos Onetti, Clarice Lispector, and Antonio Tabucchi. There are certainly distancing effects ("Neither weather nor nature will enter our report" is a typical ploy), yet for all the bold fiction of her narratives Goerke also employs what might be called sobering "autobiographical effects." The title story, for example, concludes with a statement suggesting that the main character has been an autobiographical narrator all along: "Here, however, is where the story ends, since Mrs. Zero does not know how it continues"-and this lack of knowledge suddenly perturbs us. The opening text, "Waiting Underground (Transitions)," likewise half-conceals the author in the character Transcendental Happiness, who is a Polish writer sojourning in India for six months and who observes this 
about herself: “Traveling in the imagination isn't the only way to grow, and although an American transcendentalist would have cast his veto on this point, [she] wanted to prove this to herself empirically." Goerke's writing is deeply informed by her knowledge of oriental religions and travels in the East. She studied Sanskrit in at the University of Kraków before leaving Poland in 1984. She has lived in Hamburg for over two decades.

For me, Goerke's narratives are elliptical more than absurd, circular instead of fragmentary, humorously paradoxical (in their sporting with logic) more than ludicrous, qualities that tend to emphasize extravagant amusement alone. The grotesque features of her fiction participate, not in wild Baroque whimsy, but rather in carefully meditated philosophical tales that illustrate abstract questions or, more precisely, metaphysical enigmas that resemble both Zen koans and the kind of conundrums that at once puzzle Eastern Europeans and make them laugh. In one story, the description of a painting from which all colors, even white, have faded illustrates what is at stake: "What remained was emptiness, an inviting space through which forms and contents, dreams and intentions, wonder at the ephemeral nature of existence, and the ephemeral nature of that wonder, all flickered." In another story, Goerke ponders the logical relation of what (or whom) might be a unit of what (of whom)-a spoof on nominalism, perhaps. A three-line poem sets up the riddle: "A unit of space is a pigeon / A unit of a poem is a word / But of what is John Pinstripe, Jr., a unit of?" The writer often spins little aphorisms that resemble inverted, subverted, or simply straightforward clichés ("No matter what happens, it always happens at the right time"); almost despite themselves, they offer food for thought.

"Tourists" stages one of the Buddhist ideas that engage Goerke profoundly. At the onset, a group of tourists is being shown Mt. Kanchendzonga, which the tour guide, snapping his fingers, suddenly makes disappear. The men and women are then shown a cloud, which vanishes in the same fashion. The third attraction is, as the guide explains, numerous pretas who are supposed to be visible near a lake. (A preta is a Buddhist supernatural being who, because of his or her jealousy or greed in a previous life, is now afflicted with an insatiable hunger for human feces or corpses.) When no one in the group sees anything, the guide himself disappears, remarking: "Just 
as I thought." The men and women then scatter across a field, until a new voice is heard: "We have prepared a special attraction for you today. In a moment we will find ourselves in a meadow filled with pretas." But these spectators constitute a new group of tourists who are observing the previous ones who had scattered across the field. Not surprisingly, this cyclical narrative begins and ends with the same sentence: "In the beginning, the guide paced back and forth."

Goerke has penned numerous witty, gradually disturbing fables or parables like the preceding one. Some are based on historical figures like Sir Edmund Hillary and his sherpa, Tenzing (see "Beyond Fear"), or the great Polish alpinist Wanda Rutkiewicz, who in fact lived in Wrocław for a while and earned degrees in science and electrical engineering from the Polytechnic Institute there. (In 1992, Rutkiewicz disappeared while ascending Mt. Kanchendzonga.) Sometimes Goerke's stories turn over options to the reader. In "Segment," the main character, who is described simply as a man sitting in an armchair, ends up "crammed onto the line of [the narrator's] life." Either he mutters or calls out something, or says nothing-you choose-but in all cases "the flower withered in its flowerpot."

I'll conclude this rather late letter from Wrocław-and I apologize for my tardiness - by evoking another literary radical, the poet Miron Białoszewski (1922-1983). His oeuvre was brought to my attention, by students and fellow writers alike, every single time that we discussed modern Polish literature. When I couldn't keep his name straight (and pronouncing, let alone spelling, Polish names as they are pronounced by native speakers defies even the well-meaning dabbler in languages that I am), one of my chaperones, Kasia, finally wrote it out in capital letters in my blue and green notebook; just after his name, she added a slash and wrote: "-a Polish poet (a linguist)." Indeed a master of grammatical games, puns, and colloquial speech patterns, this dark-minded, philosophically inclined scrutinizer of the humblest objects of daily life is enjoying more popularity and critical attention a quarter century after his death than during his lifetime. Outside of Poland, he remains best known for his Memoir of the Warsaw Uprising (1977), a translation of which was issued by Northwestern University Press in 1991. Anecdotes 
about Białoszewski's eccentricity abound, and he was an essential figure in underground Polish theater as well.

Few samples of his poetry are available in English, other than a long out-of-print Revolution of Things: Selected Poems (1974) that I cannot get my hands on. But I have found several poems rendered into French, including one that seems obliquely evocative of my trip-a sort of mood-stimulating memento like the bottle of Monastyrka "wódka śliwowa" (plum vodka) with which I returned to France and which I have been very careful about not emptying too fast. (A fourth of the flask remains.) Let me translate this poem for you with the help of Magdalena Heydel, whom I also met in Wrocław. A professor at the Jagiellonian University in Kraków and a specialist of Miłosz and T.S. Eliot, she is the critically acclaimed translator of works by Eliot, Virginia Woolf, Seamus Heaney, Graham Swift, Robert Hass, and Jane Hirshfield. Be careful, "uwaga"! Some of Białoszewski's cognitive shortcuts are as puzzling as those taken by e.e. cummings:

dark negative of the room

from which one daily

the sculpture has fallen out

my negative

with me

poured out into various corners

this my empty auricle-shell

my statue on the bed

oh, if only there were

a few paper flower crowns

pots

hawthorns

umbrellas beneath the drizzling night

just a few more times

I'll stick my chalk

my plaster

together 
into ever worse shapes and snails

then for real and at last

I'll fall out of my shell

so really

do remember

the umbrella.

(Yes, I was rather melancholy and it was still raining when I left Wrocław.)

BOOKS MENTIONED

Goerke, Natasza. Farewells to Plasma, translated by W. Martin. Prague, Czech Republic: Twisted Spoon Press, 2001.

Stasiuk, Andrzej. Tales of Galicia, translated by Margarita Nafpaktitis. Prague, Czech Republic: Twisted Spoon Press, 2003. . Sur la route de Babadag, translated into French by Małgorzata.

Maliszewska, Paris: Christian Bourgois, 2007.

Tokarczuk, Olga. House of Day, House of Night, translated by Antonia Lloyd-Jones. Evanston: Northwestern University Press, 2003. . Récits ultimes, translated into French by Grażyna Erhard.

Lausanne, Switzerland: Éditions Noir sur Blanc, 2007. 